Indexed by

\title{
Scopus
}

\section{FINITE ELEMENT ANALYSIS OF PUNCHING SHEAR-UNBALANCED MOMENT INTERACTIONS AT EDGE COLUMN-FLAT PLATE CONNECTIONS}

Crossref

KOBSON

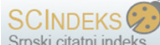

gil Google

\section{Ketut Sudarsana}

Udayana University, Department of Civil Engineering, Bali, Indonesia

\author{
Gede Gegiranang Wiryadi \\ Mahasaraswati Denpasar \\ University, Department of \\ Civil Engineering, Bali, \\ Indonesia
}

\author{
Gede Adi Susila \\ Udayana University, \\ Department of Civil \\ Engineering, Bali, \\ Indonesia
}

Key words: edge slab-column connection, shear-unbalanced moment interaction, unbalanced moment direction, finite element analysis doi:10.5937/jaes0-31703

Cite article:

Sudarsana K., Gegiranang Wiryadi G., Adi Susila G. (2022) FINITE ELEMENT ANALYSIS OF PUNCHING SHEAR-UNBALANCED MOMENT INTERACTIONS AT EDGE COLUMN-FLAT PLATE CONNECTIONS, Journal of Applied Engineering Science, 20(1), 91 - 100, DOI:10.5937/ jaes0-31703

Online aceess of full paper is available at: www.engineeringscience.rs/browse-issues 


\title{
FINITE ELEMENT ANALYSIS OF PUNCHING SHEAR-UNBALANCED MOMENT INTERACTIONS AT EDGE COLUMN-FLAT PLATE CONNECTIONS
}

\author{
Ketut Sudarsana ${ }^{1 *}$, Gede Gegiranang Wiryadi ${ }^{2}$, Gede Adi Susila ${ }^{1}$ \\ ${ }^{1}$ Udayana University, Department of Civil Engineering, Bali, Indonesia \\ ${ }^{2}$ Mahasaraswati Denpasar University, Department of Civil Engineering, Bali, Indonesia
}

The unbalance moments at the edge connections of flat plate structures induced by lateral forces (i.e. an earthquake) may not always act in parallel directions of the building axes. Most research studied the unbalanced moments in one direction, a few of them in biaxial directions, and none of them in incline directions. This paper presents the results of a nonlinear finite element analysis on punching shear capacity at edge column-slab connections subjected to three directions of the unbalanced moments namely perpendicular, incline $45^{\circ}$, and parallel to the slab free edge in combination with the shear force. A 3-D numerical analysis of ten isolated edge column-plate connections was conducted by applying an appropriate element size, mesh, and calibrated material parameters of the concrete damage plasticity (CDP) model in ABAQUS. the connections were subjected to ten variations of the moment to shear (M/V) ratios. The results show that the punching shear capacity decreases exponentially for the unbalanced moment acting perpendicular and parallel to the slab free edge, and linearly for unbalanced moment incline $45^{\circ}$ as the increase in $M N$ ratio. The $M-V$ interaction at the edge connections depends on the unbalanced moment directions which are slightly different from the $\mathrm{ACl} 318$ code.

Key words: edge slab-column connection, shear-unbalanced moment interaction, unbalanced moment direction, finite element analysis

\section{INTRODUCTION}

A flat plate reinforced concrete structure is one of the structural systems having slabs directly supported by columns without beams. The structural system has some advantages such as simplified construction by using flying formworks, reducing story height, easy to install MEP facilities. The simplifications associated with both the structural form and the technology required in their construction, are unfortunately accompanied by some difficulties in analysis and design in ensuring safety and serviceability. The main drawback of this system is the punching shear phenomenon in the slab around columns which may cause catastrophic failure. The risk of punching shear failure may increase with the presence of an unbalanced moment that is transferred from the slab to the column. Uneven gravity load distributions, different spans length, and any lateral load (i.e. earthquake or wind) can result in an unbalanced moment. In edge column-slab connections, the unbalanced moments cannot be avoided due to unbalanced slab spans and lateral loads. In high-risk seismic areas, a flat plate structure is recommended only for low-rise buildings, however, the system in high-rise buildings requires adding a special lateral force resisting system such as a shear wall or special frames [1].

The directions of earthquake excitation on the building axes can't be predicted, it can be parallel, perpendicular, or inclined with a certain angle. Some experimental researches have been done to simulate earthquake forces as biaxial loads acting perpendicularly [2] to [5]
However, the effect of an inclined moment due to earthquake force has not been investigated. Therefore, research on the directions of unbalanced moments needs to be conducted. In addition, the interaction between punching shear force and unbalanced moment at edge column-slab connection is still questionable among researchers. The ACI 318-19 takes into account part of the unbalanced moment being transferred as an eccentric shear and limits the punching shear capacity of the slab with the shear capacity of concrete only without considering the contribution of the slab reinforcement.

Experimental work is too expensive to investigate one parameter, and became more expensive if it does to investigate many parameters. A numerical approach using a finite element method (FEM) has been done by [6] - [9] to investigate the behavior of interior column-slab connections and show that the approach gives good results compared to the experimental results. Also, detailed mechanisms of stress and strain distributions of materials are difficult to visualize in experimental work, however, they can be easily obtained using finite element analysis [10] and [11]. Therefore, a numerical approach using a finite element method (FEM) was used to investigate some parameters in this study namely the directions of unbalanced moments and the ratio of $\mathrm{M} / \mathrm{V}$ to develop moment-shear interaction of the edge connections. 


\section{ACI CODE PREDICTION ON PUNCHING SHEAR}

The ACI 318-19 code, assumes a critical shear section located at $\mathrm{d} / 2$ from the loaded area or column faces. When gravity load, wind, earthquake, or other lateral forces exist in the structure and cause a transfer of unbalanced moment $\left(\mathrm{M}_{\mathrm{sc}}\right)$ from a slab to a column, a portion of this moment $\left({ }_{v v} M_{s c}\right)$ is transferred by eccentric shear which is assumed to vary linearly about the centroid of the critical shear section. The rest of the unbalanced moments is transferred by flexure $\left({ }_{\mathrm{rf}} \mathrm{M}_{\mathrm{sc}}\right)$ within the column strip of the slab. The shear stress distribution along the critical section for the $M_{s c}$ acting perpendicular to the slab-free edge is shown in Figure 1.
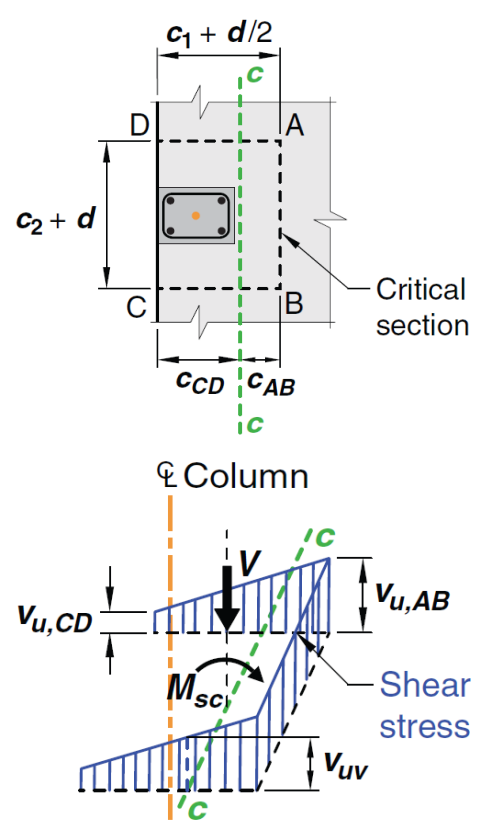

Figure 1: A critical section of the slab around a column on edge slab-column connection

The nominal shear stress along perimeter $A B$ and $C D$ in the Figure $1, \mathrm{v}_{\mathrm{u}, \mathrm{AB}}$ or $\mathrm{v}_{\mathrm{u}, \mathrm{CD}}$, is determined using:

$v_{u, A B}=\frac{V_{u}}{A_{c}}+\frac{V_{v} M_{s c} c_{A B}}{J_{c}}$ or $v_{u, C D}=\frac{V_{u}}{A_{c}}-\frac{V_{v} M_{s c} c_{C D}}{J_{c}}$

$\gamma_{v}=1-y_{f}=1-\frac{1}{1+\left(\frac{2}{3}\right) \sqrt{\frac{b_{1}}{b_{2}}}}$

Where $b_{1}$ and $b_{2}$ are the sides of the control perimeter of a rectangular column, perpendicular and parallel to the unbalanced moment vector, respectively, $M_{s c}$ is the unbalanced moment acting at the centroid of the critical section, and $c$ is a distance from the centroid of the critical section to the side of the critical section $\left(\mathrm{C}_{\mathrm{AB}}\right.$ or $\left.\mathrm{C}_{\mathrm{CD}}\right)$. $V_{u}$ is the factored shear force. The $A_{c}$ and $J_{c}$ in Equation 1 are areas of the critical section calculated from the circumference of the critical section $\left(b_{0}\right)$ multiplied by the effective slab depth (d) and the polar inertia of the critical section, respectively. The value of $A_{c}$ and $J_{c}$ for the stress distribution in Figure 1 is given in Equation 3 and Equation 4.

$$
\begin{aligned}
& A_{c}=b_{0} d=\left(c_{2}+d+2\left(c_{1}+d / 2\right)\right) d \\
& J_{c}=\frac{\left(c_{1}+d\right)^{3}}{6}+\frac{\left(c_{1}+d\right) d^{3}}{6}+\frac{d\left(c_{2}+d\right)\left(c_{1}+d\right)^{2}}{2}
\end{aligned}
$$

The ACI 318-19 allows a reduction on the fraction of $M_{s c}$ to be transferred as an eccentric shear. For edge column-slab connections, when $M_{s c}$ is resisted about the axis parallel to slab free edge, the value of ${ }_{y v} M_{s c}$ can be reduced to zero as long as the shear stress at the critical shear section due to gravity loads $\left(\mathrm{v}_{\mathrm{ug}}\right)$ does not exceed $0.75 \varnothing_{\mathrm{vc}}$ and tension strain of slab rebars $\left(\varepsilon_{\mathrm{t}}\right)$ does not less than 0.004 . This type of exterior connection [12] indicates that there is no significant interaction between shear $\left(\mathrm{V}_{\mathrm{u}}\right)$ and Msc at the connections. When Msc is resisted about the axis perpendicular to slab free edge, the value of ${ }_{v v} \mathrm{M}_{\mathrm{sc}}$ can be reduced up to 0.25 as long as the value of vug does not exceed $0.4 \varnothing_{\mathrm{vc}}$ and the value of $\varepsilon_{\mathrm{t}}$ does not less than 0.01 . The Moment of the critical section $\left(M_{s c}\right)$ at the square column-slab connections should be $60 \%$ transferred by flexure and $40 \%$ transferred by eccentric shear.

The maximum shear stress of the concrete with a specified concrete strength of $f_{c}$ for two-way shear $\left(v_{c}\right)$ is given by the smallest value of Equation 5 to Equation 7.

$v_{c}=0.33 \lambda_{s} \lambda \sqrt{f_{c}^{\prime}}$

$v_{c}=\left(0.17+\frac{0.33}{\beta}\right) \lambda_{s} \lambda \sqrt{f_{c}^{\prime}}$

$v_{c}=\left(0.17+\frac{0.083 \alpha_{s} d}{b_{0}}\right) \lambda_{s} \lambda \sqrt{f_{c}^{\prime}}$

The parameter $\beta$ in Equation 6 is the ratio of the length of the long and short side of a rectangular column or a loaded area which is larger than 2.0. The value of as is 30 for the edge column, the value of $\lambda$ is 1.0 for normal concrete strength and $\lambda_{s}$ is 1.0 for the size effect modification factor. Using the expression in Equation 1 and the limiting shear stress given in Equation 5 to Equation 7, the maximum shear force in the absence of an unbalanced moment $\left(\mathrm{V}_{\mathrm{o}, \mathrm{ACl}}\right)$ and the maximum of an unbalanced moment in the absence of the shear force $\left(\mathrm{M}_{\mathrm{o}, \mathrm{ACl}}\right)$ can be calculated using Equation 8 and Equation 9 , respectively.

$V_{0 . A C l}=V_{c} A_{c}$

$M_{0 . A C l}=\frac{v_{c} J_{c}}{V_{v} c}$

\section{RESEARCH METHODS}

\section{Specimens Data}

The specimens model was subassembly edge column-plate connections as part of a previously designed three-story flat plate structure for an office building with the column to column span of 3.0 meters in both direc- 
tions. The structural design followed the Indonesian Code (SNI 2847:2019) [13] for structural concrete requirements and the Indonesian seismic code (SNI 1726:2019) [14] for designing seismic loads. The detailed design of the structure can be seen in [15]. The subassembly edge column-slab connection has a slab dimension of $1625 \mathrm{x}$ $3000 \times 120 \mathrm{~mm}$ and a column dimension of $250 \times 250$ $\mathrm{mm}$. The height of column stubs was $1000 \mathrm{~mm}$ above and below the slab surfaces giving a total height of 2120 $\mathrm{mm}$. Deformed rebar with a diameter of $10 \mathrm{~mm}$ (D10) was used for the top and bottom slab reinforcement with detailed placement spacing shown in Figure 2. The column stubs were reinforced with 8D16 (8 pcs) deformed rebar with a diameter of $16 \mathrm{~mm}$ for longitudinal reinforcement and plain rebar diameter of $8 \mathrm{~mm}$ with a spacing of $100 \mathrm{~mm}$ for transverse reinforcement.

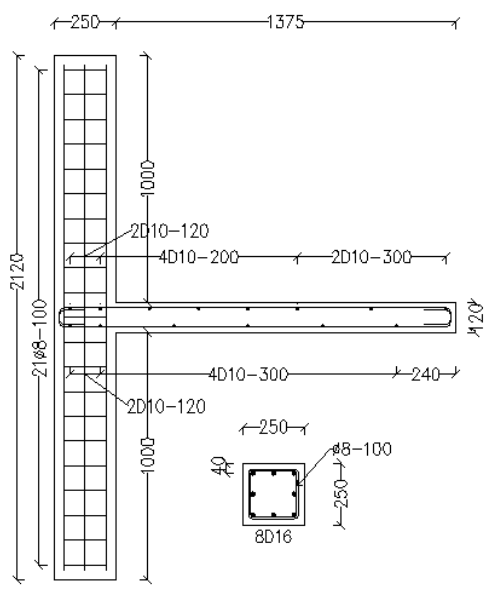

(a)

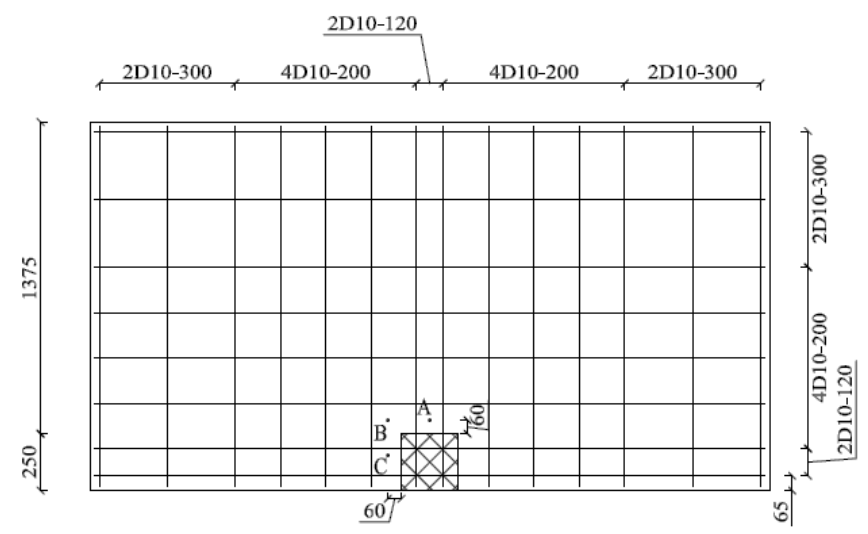

(b)

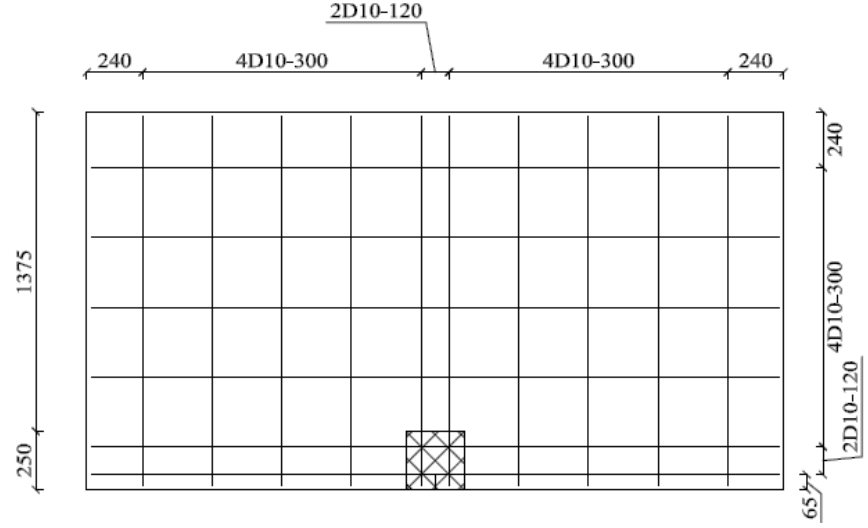

(c)

Figure 2: Dimension and reinforced column and slab

Material properties for all analysis models are given in Table 1. The stress-strain diagram of the concrete follows the Hognestad model curve [16] for normal concrete with a modulus of elasticity $\left(E_{c}\right)$ and poison ratio $(v)$ defined in $\mathrm{ACl}$ 318-19 code. The stress-strain diagram of steel rebar was assumed to be elastoplastic with yield and ultimate points.

The slab was assumed to be simply supported along the three edges with a loading scheme was defined as shown in Figure 3. The loads were applied through the column stubs in which the shear force was applied as a vertical force (perpendicular to the slab surface) and the unbalanced moment was obtained from two equal horizontal forces acting on both ends of the column's stubs.

The $45^{\circ}$ inclined unbalance moment was exerted by two simultaneously applied horizontal loads perpendicular to each other. As many as 10 specimen models were analyzed with variations in the eccentricity $(e=M / V)$ namely $0.1,0.2,0.3,0.4,0.5,0.6,1,1.4$, and shear force only $(\mathrm{V}, \mathrm{e}=0)$ and unbalanced moment only $(\mathrm{M}, \mathrm{e}=\infty)$ to investigate the interaction between the shear forces and unbalanced moments.

\section{Finite Element Simulations}

Nonlinear finite element analysis was done using Abaqus/Standard software. Concrete Damage Plasticity (CDP) features in Abaqus were used to model the damage behavior of concrete. The CDP features are a method based on plasticity proposed by Lubliner [17] and modified by Lee \& Fenves [18]. Many researchers have

Table 1: Property of materials

\begin{tabular}{|c|c|c|c|c|}
\hline \multicolumn{5}{|c|}{ Concrete data } \\
\hline $\begin{array}{c}\text { Compressive } \\
\text { strength, } \mathrm{f}_{\mathrm{c}}(\mathrm{MPa})\end{array}$ & $\begin{array}{c}\text { Tension strength, } \\
\mathrm{f}_{\mathrm{ct}}(\mathrm{MPa})\end{array}$ & $\begin{array}{c}\text { Modulus Elasticity, } \\
\mathrm{E}_{\mathrm{c}}(\mathrm{MPa})\end{array}$ & $\begin{array}{c}\text { Strain at peak com- } \\
\text { pression stress, } \varepsilon_{\mathrm{co}}\end{array}$ & $\begin{array}{c}\text { Strain at peak ten- } \\
\text { sion stress, } \varepsilon_{\mathrm{t}}\end{array}$ \\
\hline 30 & 1.81 & 25742 & 0.0023 & 0.00007 \\
\hline \multicolumn{5}{|c|}{ Steel reinforcement data } \\
\hline $\begin{array}{c}\text { Yield stress, } \mathrm{f}_{\mathrm{y}} \\
(\mathrm{MPa})\end{array}$ & $\begin{array}{c}\text { Tension strength, } \mathrm{f}_{\mathrm{u}} \\
(\mathrm{MPa})\end{array}$ & $\begin{array}{c}\text { Modulus Elasticity, } \\
\mathrm{E}_{\mathrm{s}}(\mathrm{MPa})\end{array}$ & Yield strain, $\varepsilon_{\mathrm{y}}$ & Ultimate strain, $\varepsilon_{\mathrm{u}}$ \\
\hline 400 & 600 & 200000 & 0.002 & 0.1 \\
\hline
\end{tabular}



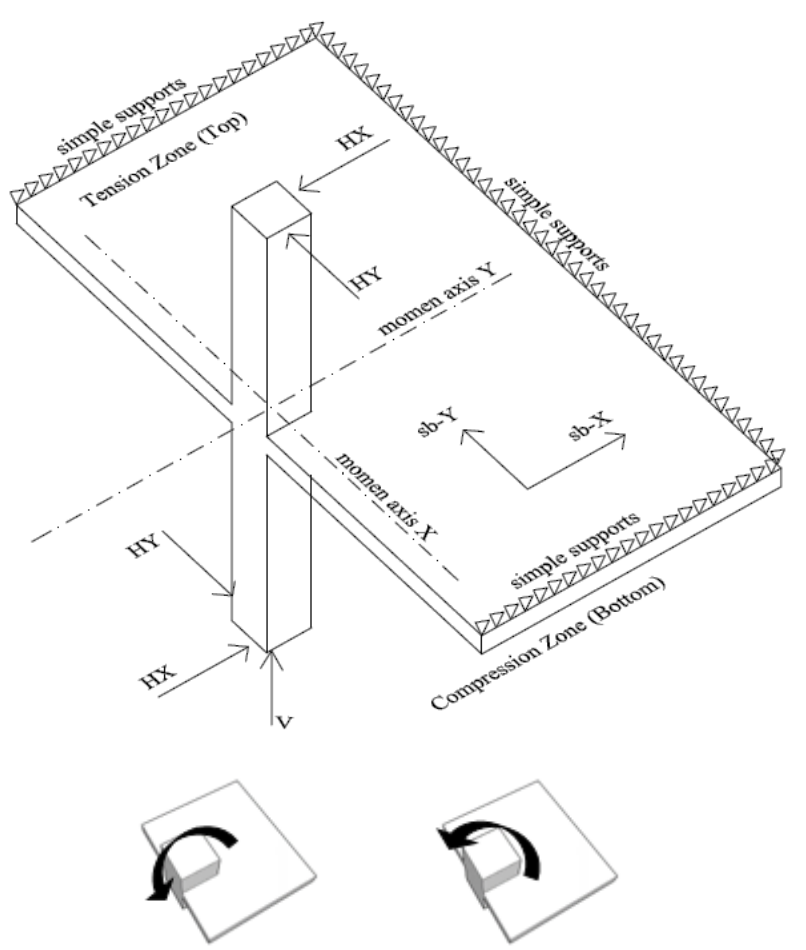

(a) perpendicular

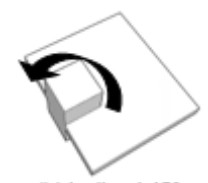

(b) inclined $45^{\circ}$

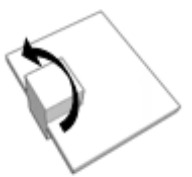

(c) parallel

Figure 3: Loading and support scheme (top); unbalanced moment directions (bottom)

proven the ability of the CDP Model in modeling the plastic behavior of concrete [9], [19] to [21]. It is required a sensitive analysis process to obtain a convergence value for the CDPs parameters namely the dilation angle $(\psi)$, the eccentricity $(\varepsilon)$ the ratio between biaxial and the uniaxial compressive strength of concrete $\left(\sigma_{b o} / \sigma_{c 0}\right)$, the ratio of von misses equivalent stress on the tensile and compression meridian $\left(\mathrm{K}_{\mathrm{c}}\right)$, and the viscosity $(\mu)$. It is also important to define the tensile strain, and the use of damage mode on the strain and compressive behavior in the analysis. Also, considering most of the plasticity-based models are meshed size-dependent [9], a mesh sensitivity study was conducted.

Investigation of material parameters of the CDP model and calibration of the modeling technique was already conducted using the experimental results of specimen code XXX tested by El-salakawy [22] as reported in Sudarsana [23]. In modeling the specimens, the concrete was modeled as 3D stress element 8-nodes hexahedral (bricks) with reduced integration (C3D8R) and steel rebar modeled as 2-nodes linear truss element (T3D2). Modeling of reinforcement using a 3D element or truss element gives equivalent results [24]. Therefore, the truss element was chosen to reduce the analysis time. Concrete and rebar were assumed to have a perfect bond which was defined using an embedded region. As many as nineteen models have been analyzed to obtain the convergence value of CDP's parameters. As many as four mesh sizes were evaluated for mesh sensitivity namely $30 \mathrm{~mm}, 40 \mathrm{~mm}, 50 \mathrm{~mm}$, and $60 \mathrm{~mm}$. The chosen mesh sizes are greater than the maximum aggregate sizes [9]. It was found that the mesh size of $60 \mathrm{~mm}$ gave the closest results to experimental data. Details of the calibration model can be found in [23]. After trial and errors process, and with a mesh size of $60 \mathrm{~mm}$, it was found that the values of CDPs parameters were dilation angle $\psi=40^{\circ}$, eccentricity $\varepsilon=0.1, \mathrm{~K}_{\mathrm{c}}=2 / 3$, ratio $\sigma \mathrm{bo} / \sigma \mathrm{cco}$ $=1.16$, and viscosity parameter $\mu=0.00005$. Applying all values in the numerical model, considering the tensile strain on the tension behavior, and using damage parameters of compression and tension gave good results to the experimental results as shown in Figure 4. The validated parameters obtained from the sensitivity analysis were then be used in the modeling of the specimen model in Figure 2 with a variation on the $M / \mathrm{V}$ ratio to investigate the behavior of punching shear failure and the interaction of punching shear and unbalanced moment at the edge column-slab connections.
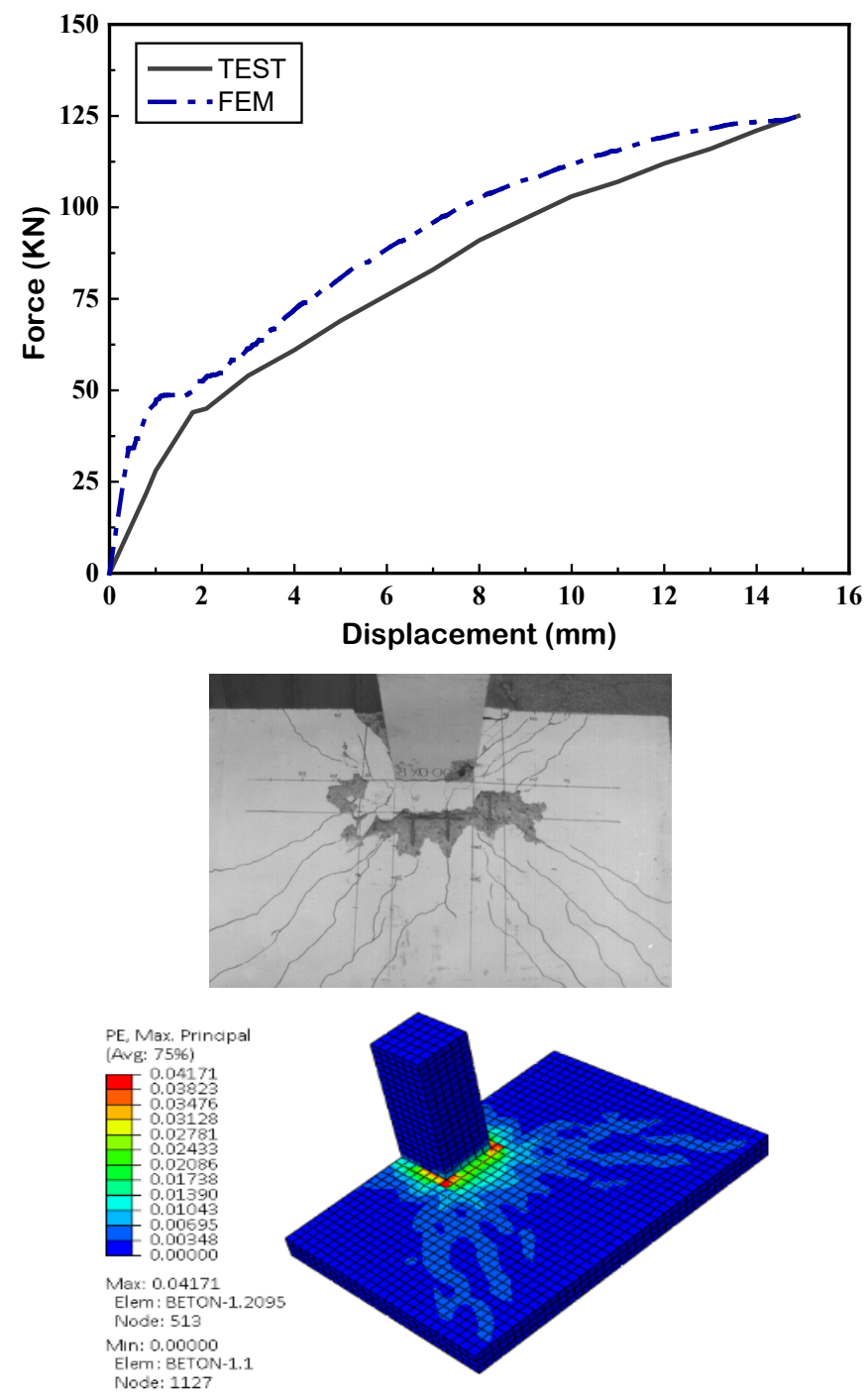

Figure 4: Comparison of experimental and FEM results of validated specimen XXX tested by El-Salakawy

(1998) 
Table 2: Maximum shear force and unbalanced moment for moment directions to free edges

\begin{tabular}{|c|c|c|c|c|c|c|}
\hline \multirow{2}{*}{ e = M/V } & \multicolumn{2}{|c|}{ Perpendicular } & \multicolumn{2}{c|}{ Incline 45 } & \multicolumn{2}{c|}{ Parallel } \\
\cline { 2 - 7 } & Shear Force (V) & Moment (M) & Shear Force (V) & Moment (M) & Shear Force (V) & Moment (M) \\
\hline$(\mathrm{m})$ & $(\mathrm{kN})$ & $(\mathrm{kNm})$ & $(\mathrm{kN})$ & $(\mathrm{kNm})$ & $(\mathrm{kN})$ & $(\mathrm{kNm})$ \\
\hline 0 & 91.84 & - & 91.84 & - & 91.84 & - \\
\hline 0.1 & 81.66 & 8.17 & 80.00 & 8.00 & 74.61 & 7.46 \\
\hline 0.2 & 83.66 & 16.73 & 79.68 & 15.94 & 68.54 & 13.71 \\
\hline 0.3 & 91.08 & 27.33 & 80.34 & 24.10 & 65.06 & 19.52 \\
\hline 0.4 & 84.31 & 33.72 & 78.06 & 31.23 & 60.41 & 24.16 \\
\hline 0.5 & 69.51 & 34.75 & 75.56 & 37.78 & 56.69 & 28.34 \\
\hline 0.6 & 58.81 & 35.28 & 72.66 & 43.59 & 52.65 & 31.59 \\
\hline 1.0 & 33.92 & 33.92 & 56.45 & 56.45 & 42.44 & 42.44 \\
\hline 1.4 & 23.63 & 33.08 & 32.38 & 45.33 & 31.57 & 44.20 \\
\hline$\infty$ & - & 32.86 & - & 40.86 & - & 51.50 \\
\hline
\end{tabular}

\section{RESULTS AND DISCUSSION}

\section{Connection Capacity}

The shear forces $(\mathrm{V})$ and unbalanced moments $(\mathrm{M})$ that can be resisted by the connections with the applied ratio of $\mathrm{M} / \mathrm{V}$ and the unbalanced moment directions are presented in Table 2. The analysis results show that for $M / V$ ratio $(e)<0.4$, the punching shear capacity of the connections decreases as the unbalanced moment directions changes from the perpendicular, incline $45^{\circ}$, and parallel to the slab free edge. For the eccentricity (e) of 0.5 and 0.6 , the maximum loads can be resisted by the connections with the direction of unbalanced moment incline $45^{\circ}$ to the free edge and the minimum loads occurred in the connection with unbalanced moment parallel to the slab free edge. For the value of $M / V=1.0$ and $M / V=1.4$, the maximum load can be resisted by the connections with an unbalanced moment incline $45^{\circ}$ to the slab free edge and the minimum loads in the connections with the unbalanced moment perpendicular to the slab free edge.

The results also indicate that the connections subjected to dominant shear forces $(M / V<0.5)$, the capacity of connections with a perpendicular moment is greater than that of the connections with parallel moments. This may due to the contribution of torsional resistance provided by part of the slab in column strips parallel to the free edge. On the other hand, for the connections subjected to dominant moments $(M / V>1.0)$, the capacity of the connections with unbalanced moments parallel to the slab free edge is higher than that of the connections with unbalanced moments perpendicular to the slab free edge. This may be as the results of continuous slab span on both sides of the column and torsion resistance of the slab in column strip perpendicular to the free edge. This is also shown by the results of the connections with pure bending. Table 2 also shows that as the unbalanced moment directions changes from perpendicular to parallel the slab free edge, the shear and moment capacities of the connections change reversely down and up, respectively, at a certain value of the $M / V$ ratio. Using the capacities of the connections subjected to perpendicular moment as a reference, the threshold value of the $\mathrm{M} / \mathrm{V}$ ratio was 0.5 for the inclined $45^{\circ}$ unbalanced moment and 1.0 for an unbalanced moment parallel to the free edge.

\section{Principal Strain on The Concrete Slab}

The principal strains at the maximum loads on the tension side of the concrete slab and section through column axis for only the connections subjected to inclined $45^{\circ}$ unbalanced moment directions with the eccentricities $(\mathrm{e}=\mathrm{M} / \mathrm{V}$ ) of 0 (shear only), 0.3 , and $\infty$ (moment only), are presented in Figure 5 to Figure 7, respectively. The other principle strains can be found in [15].

\section{Stress on Steel Reinforcement}

Four rebars are passing through the column faces both perpendicular and parallel to the slab free edge as shown in Figure 2(b), (c). Every two rebar are placed on the tension side as tension reinforcement and the compression side as compression reinforcement. The maximum stresses of all reinforcement passing through the column at column faces for all $M / V$ ratios are given in Figure 8 to Figure 10 for unbalanced moment perpendicular, inclined $45^{\circ}$, and parallel to the slab free edge, respectively. It is shown that almost all rebars in the direction parallel to the unbalanced moment directions reach yield limit (400 MPa) both tension and compression rebar. In the connections with the unbalanced moment perpendicular to the free edge, only tension rebars reach the yield limit for $M / V<0.6$. This indicates that shear force causes the rebar yield but not the torsional moment. It is also clearly seen in the connections subjected to an unbalanced moment parallel to the slab free edge. In the connections with unbalanced moment inclined $45^{\circ}$ to slab free edge show all rebar perpendicular and parallel 


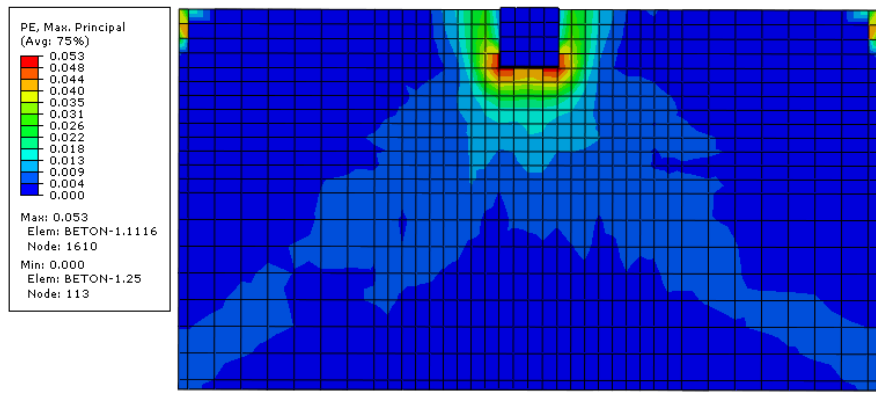

(a)

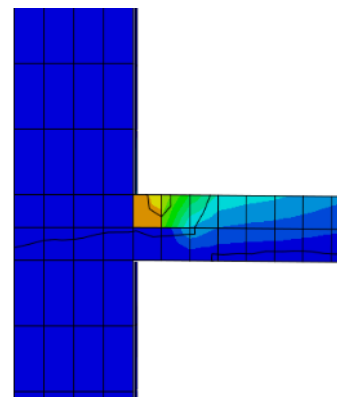

(b)

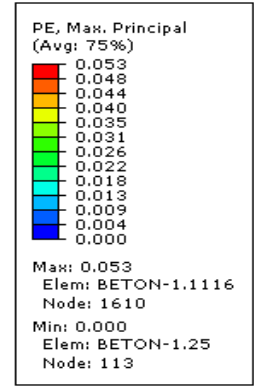

Figure 5: Principal strain for the model connection with $M / V=0$

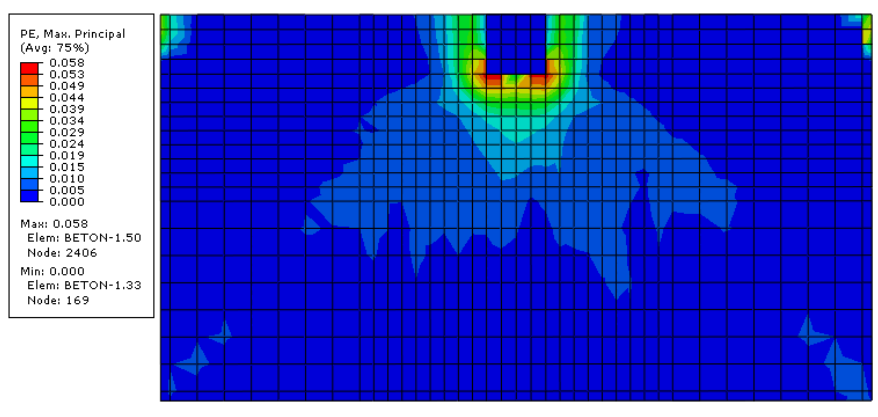

(a)

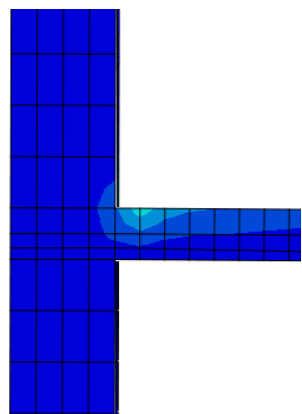

(b)

Figure 6: Principal strain (a) and perpendicular free edge section (b) for $M N=0.3$

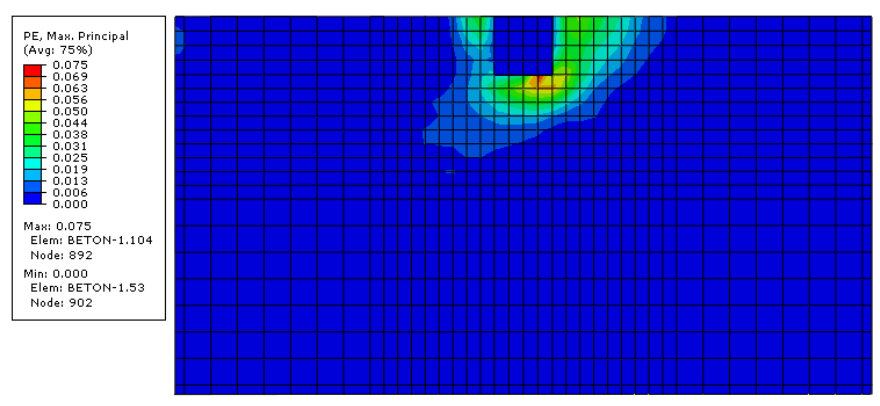

(a)

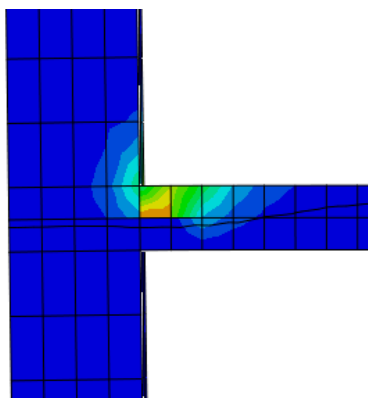

(b)

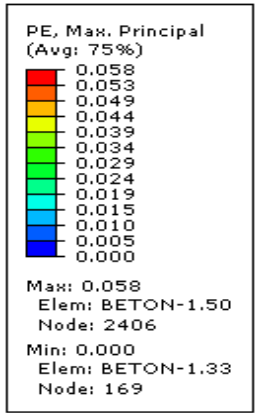

Node: 169 (b)

Figure 7: Principal strain (a) and perpendicular free edge section (b) for $M N=\infty$

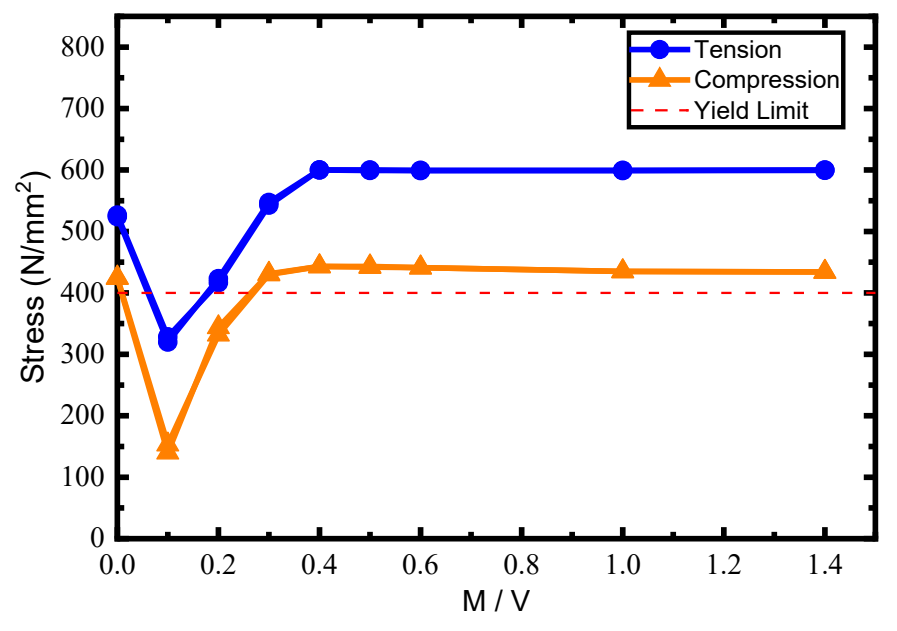

(a)

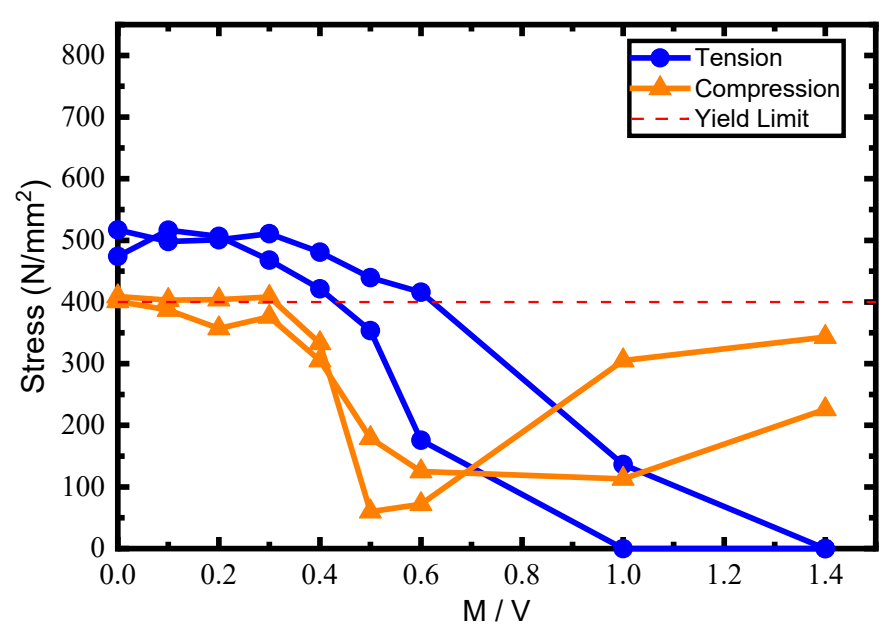

(b)

Figure 8: Eccentricity effect to rebar stress with moment perpendicular to free edge at ultimate loads 


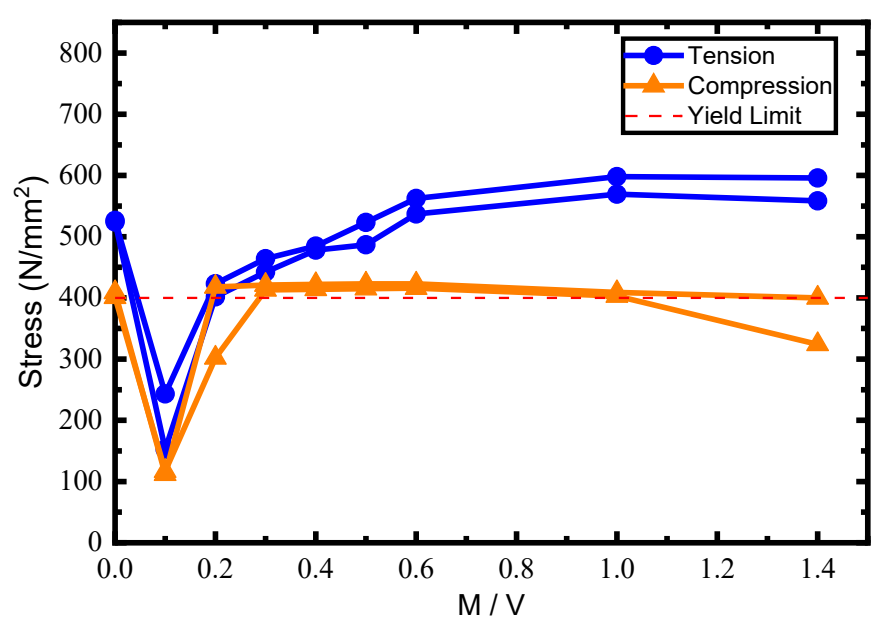

(a)

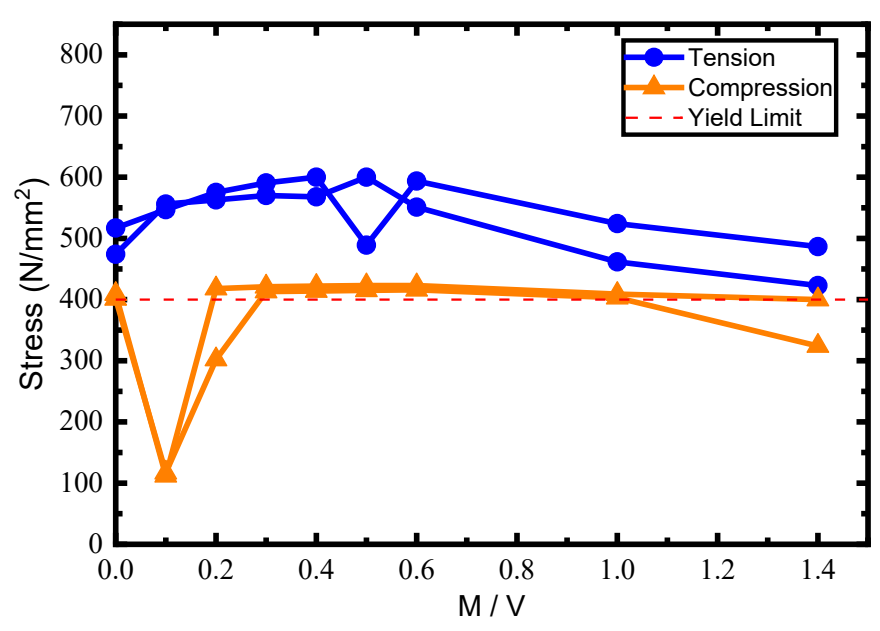

(b)

Figure 9: Eccentricity effect to rebars stress with moment incline $45^{\circ}$ to free edge at ultimate loads

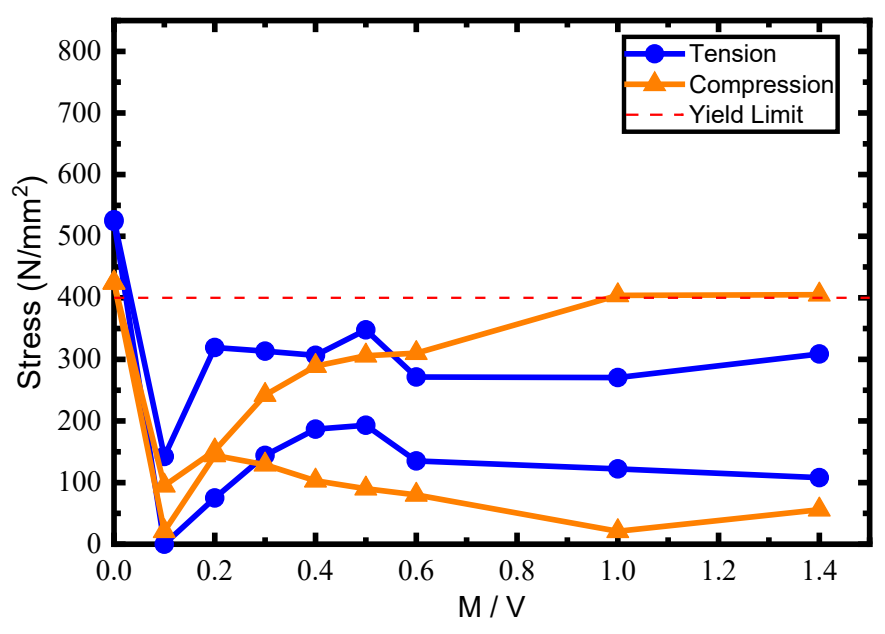

(a)

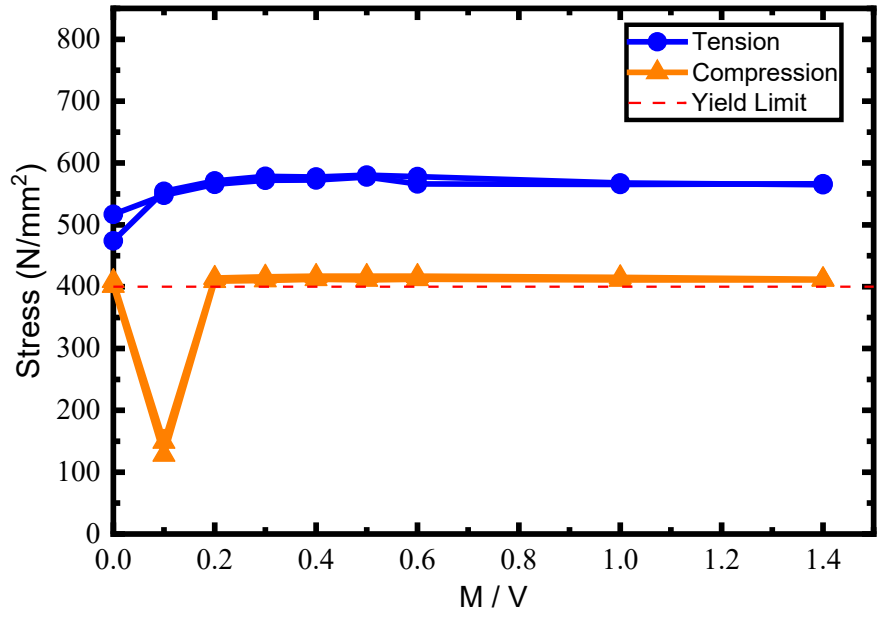

(b)

Figure 10: Eccentricity effect to rebar stress with moment parallel to the free edge at ultimate loads

the free edge exceeds limit yield stress, except for $\mathrm{M} /$ $V=0.1$. For the connections subjected to shear force only, all rebars reach the yield limit. The stress condition of the rebar passing through the column indicates that the slab tension reinforcement gives a certain contribution to punching shear resistance of the column-slab connections as proposed by CEB-FIP [25], and Gardner \& Shao [26]. The experimental test done by [27], indicated the same phenomena in which the yield strength of the rebar passing through the column reaches before the punching failure occurs indicated that punching shear is not a pure shear failure rather than a flexure-shear failure. These phenomena show that the effect of the reinforcement ratio should be included in the expression used to predict the punching capacity of the slab column connections. This effect has not been taken into account in the ACl 318 code.

\section{Stress on Steel Reinforcement}

Four rebars are passing through the column faces both perpendicular and parallel to the slab free edge as shown in Figure 2(b), (c). Every two rebar are placed on the tension side as tension reinforcement and the compression side as compression reinforcement. The maximum stresses of all reinforcement passing through the column at column faces for all $M / V$ ratios are given in Figure 8 to Figure 10 for unbalanced moment perpendicular, inclined $45^{\circ}$, and parallel to the slab free edge, respectively. It is shown that almost all rebars in the direction parallel to the unbalanced moment directions reach yield limit (400 MPa) both tension and compression rebar. In the connections with the unbalanced moment perpendicular to the free edge, only tension rebars reach the yield limit for $M / V<0.6$. This indicates that shear force causes the rebar yield but not the torsional moment. It is also clearly seen in the connections subjected to an unbalanced moment parallel to the slab free edge. In the connections with unbalanced moment inclined $45^{\circ}$ to slab free edge show all rebar perpendicular and parallel the free edge exceeds limit yield stress, except for $M / V$ $=0.1$. For the connections subjected to shear force only, all rebars reach the yield limit. The stress condition of the rebar passing through the column indicates that the slab tension reinforcement gives a certain contribution to punching shear resistance of the column-slab connec- 
Table 3: The shear forces and moments according to ACI 318-19 at the critical section

\begin{tabular}{|c|c|c|c|c|c|c|}
\hline \multirow[b]{2}{*}{$e=M / V$} & \multicolumn{2}{|c|}{ Perpendicular } & \multicolumn{2}{|c|}{ Incline $45^{\circ}$} & \multicolumn{2}{|c|}{ Parallel } \\
\hline & Shear Force $\mathrm{V}_{0, \mathrm{ACl}}$ & Moment $\mathrm{M}_{0, \mathrm{ACl}}$ & Shear Force $\mathrm{V}_{0, \mathrm{ACl}}$ & $\begin{array}{c}\text { Moment } \\
\mathrm{M}_{0 . \mathrm{ACl}}\end{array}$ & $\begin{array}{c}\text { Shear Force } \\
V_{0, A C I}\end{array}$ & Moment $\mathrm{M}_{0, \mathrm{AC}}$ \\
\hline$(\mathrm{m})$ & $(\mathrm{KN})$ & $(\mathrm{KNm})$ & $(\mathrm{KN})$ & $(\mathrm{KNm})$ & $(\mathrm{KN})$ & $(\mathrm{KNm})$ \\
\hline 0 & 173.27 & - & 173.27 & - & 173.27 & - \\
\hline 0.1 & 130.49 & 13.05 & 127.16 & 12.72 & 123.41 & 12.34 \\
\hline 0.2 & 104.66 & 20.93 & 100.44 & 20.09 & 95.83 & 19.17 \\
\hline 0.3 & 87.36 & 26.21 & 82.99 & 24.90 & 78.33 & 23.50 \\
\hline 0.4 & 74.97 & 29.99 & 70.71 & 28.29 & 66.23 & 26.49 \\
\hline 0.5 & 65.66 & 32.83 & 61.60 & 30.80 & 57.37 & 28.69 \\
\hline 0.6 & 58.40 & 35.04 & 54.56 & 32.74 & 50.60 & 30.36 \\
\hline 1.0 & 40.50 & 40.50 & 37.46 & 37.46 & 34.38 & 34.38 \\
\hline 1.4 & 31.00 & 43.40 & 28.52 & 39.92 & 26.03 & 36.44 \\
\hline$\infty$ & - & 24.39 & - & 35.26 & - & 42.88 \\
\hline
\end{tabular}

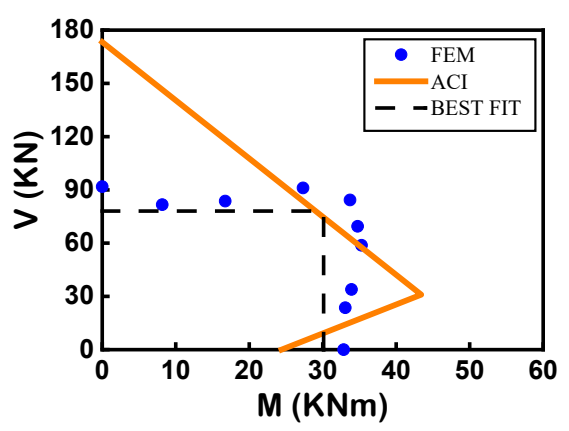

(a)

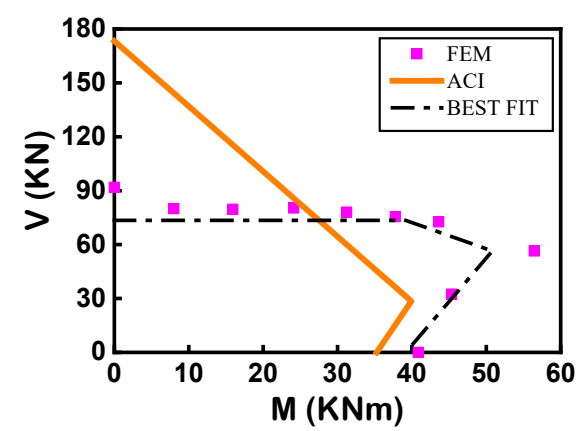

(b)

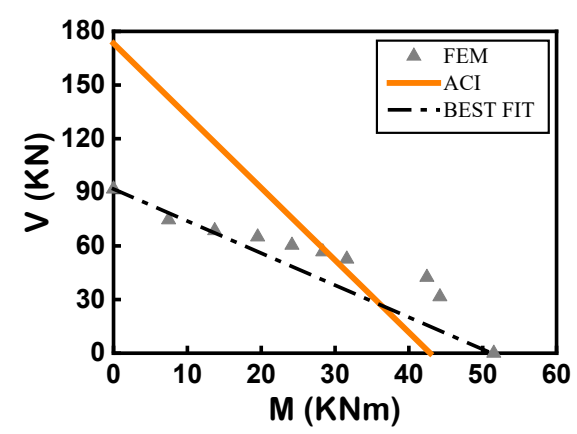

(c)

Figure 11: Interaction between shear forces and moments compared to ACI 318 prediction

tions as proposed by CEB-FIP [25], and Gardner \& Shao [26]. The experimental test done by [27], indicated the same phenomena in which the yield strength of the rebar passing through the column reaches before the punching failure occurs indicated that punching shear is not a pure shear failure rather than a flexure-shear failure. These phenomena show that the effect of the reinforcement ratio should be included in the expression used to predict the punching capacity of the slab column connections. This effect has not been taken into account in the $\mathrm{ACl} 318$ code.

\section{Comparison to Code Prediction}

The prediction of shear forces $\left(\mathrm{V}_{\mathrm{ACl}}\right)$ and unbalanced moments $\left(\mathrm{M}_{\mathrm{o}, \mathrm{ACl}}\right)$ of the $\mathrm{ACl} 318-19$ were calculated using Equation 8 and Equation 9 by assuming a linear distribution of the maximum shear stress obtained from Equation 5 to Equation 7 along the critical shear section. Table 4 presents the capacity of the connection following the $\mathrm{ACl} 318-19$ code that was calculated at the centroid of the shear critical section for all parameter $\mathrm{M} / \mathrm{V}$ ratios in all unbalanced moment directions. The shear forces and moments are given in Table 3 were adjusted to work at the column centroid before plotting together with the finite element results given in Table 2 as shown in Figure 11. When low unbalanced moment working on the connection, $\mathrm{ACl} 318$ gives overestimates capacity than finite element analysis. Figure 11 shows a significant difference between the results of finite element analysis and prediction given by $\mathrm{ACl} 318$. The interaction diagram at the connections where the unbalanced moment acting perpendicular to the slab free edge follows a rectangular shape as shown in Figure 11 (a). In this connection, the maximum shear force is almost half of the $\mathrm{ACl}$ prediction and the maximum moment is limited by the flexural moment of the slab reinforcement within the column strips. The analysis results show no special interaction between shear force and unbalanced moment as proposed by Moehle [12] or modification of Gardner and Shao [26].

The effect of the unbalanced moment on the shear force capacity of column-slab connections may also be evaluated from the relationship of $\mathrm{M} / \mathrm{V}$ ratios and shear forces. The analysis results together with $\mathrm{ACl} 318$ predictions were plotted as shown in Figure 12 where the $\mathrm{ACI} 318$ code predicts the punching shear capacity of the edge column-slab connections decreasing exponentially as the $\mathrm{M} / \mathrm{V}$ ratio increases for all types of connections. However, the analysis results show different trends of decreasing 


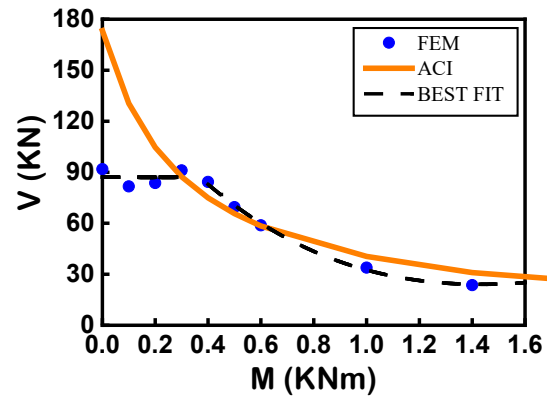

(a)

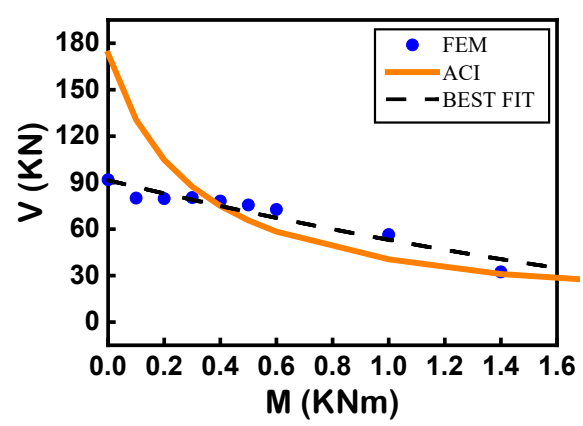

(b)

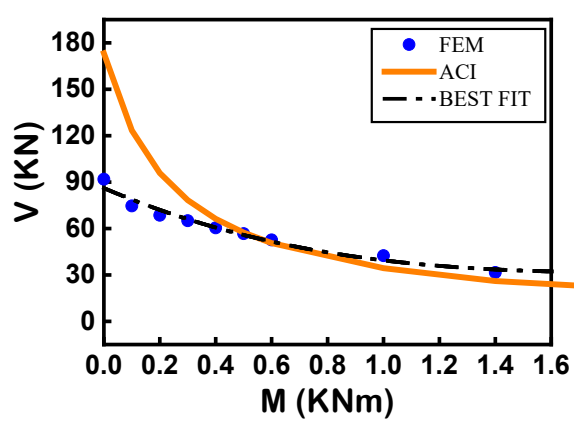

(c)

Figure 12: Eccentricity (e=M/V) effect on shear capacity

the punching shear capacity that depends on the direction of unbalanced moments. For the connections with unbalanced moments that act perpendicular to slab free edge, the shear capacity decreases exponentially following the $\mathrm{ACl} 318$ starting from M/N ratio of 0.3 , but before that point, the shear capacity does not change significantly as seen in Figure 12(a). For the connections with the direction of an unbalanced moment inclined $45^{\circ}$ to slab free edge, the shear capacity decreases linearly as the $\mathrm{M} / \mathrm{V}$ ratio increases as shown in Figure 12(b). Exponentially decreases in the shear capacity as in the ACI 318 occurs in the connection with the unbalanced moments acting parallel to slab free edge. It is also shown in Figure 12 , the shear capacity of the $\mathrm{ACI} 318$ code overestimates the shear capacity for an M/V ratio of less than 0.3 .

\section{CONCLUSION}

Nonlinear finite element analysis applying the calibrated material parameters of the CDP model in Abaqus predicts well the punching shear behavior of edge column-slab connection subjected to shear force and unbalanced moment in any direction. The results show that the punching shear capacity of the connections decreases as the M/V ratio increases. The unbalanced moment directions also affected the connections' capacity. As the unbalanced moment directions changes from perpendicular to parallel the slab free edge, the shear and moment capacities of the connections change reversely down and up, respectively, at a certain value of the M/V ratio. Using the capacities of the connections subjected to perpendicular moment as a reference, the threshold value of the M/V ratio was 0.5 for the inclined $45^{\circ}$ unbalanced moment and 1.0 for an unbalanced moment parallel to the free edge. The analysis also shows that almost all tension rebar passing through the column faces at the direction of applied moment yield at the failure loads. The $\mathrm{M}-\mathrm{V}$ interactions at edge column slab connections depend on the unbalanced moment directions which are different from the assumed interaction in the $\mathrm{ACI} 318$ code. The reduction in punching shear capacity of the connections as the increase in the $M / V$ ratios shows different trends from the $\mathrm{ACl} 318$ code prediction, especially when the connections are subjected to dominant shear with the M/V ratio less than $0.3,0.3$, and 0.4 , respectively for the direction of unbalanced moments perpendicular, inclined $45^{\circ}$, and parallel to the slab free edge, where the $\mathrm{ACl} 318$ code predicts the shear capacity much higher. These results were based on finite element analysis so that further experimental tests are needed.

\section{REFERENCES}

1. $\mathrm{ACl}$ Committee 318 (2019) Building Code Requirements for Structural Concrete and Commentary (ACl 318M-19). Farmington Hills

2. Widianto, Bayrak O, Jirsa JO (2009) Two-Way Shear Strenght of Slab-Column Connections: Reexamination of $\mathrm{ACl} 318$ Provisions. $\mathrm{ACl}$ Structural Journal 106: $160-170$

3. Moehle JP (1988) Strength of Slab-Column Edge Connection. ACI Structural Journal 85:89-98

4. Matzke EM, Lequesne RD, Parra-montesinos GJ, Shield CK (2015) Behavior of Biaxially Loaded Slab-Column Connections with Shear Studs. ACl Structural Journal 112:335-346. https://doi. org/10.14359/51687408

5. Kang SM, Na SJ, Hwang HJ (2021) Two-way shear strength of reinforced concrete transfer slab-column connections. Engineering Structures 231:2020-2021. https://doi.org/10.1016/j.engstruct.2020.111693

6. Milligan GJ, Polak MA, Zurell C (2020) Finite element analysis of punching shear behavior of concrete slabs supported on rectangular columns. Engineering Structures 224:111189. https://doi.org/10.1016/j. engstruct.2020.111189

7. Filatov VB, Galyautdinov ZS, Blinkova E V., Zhiltsov YV (2020) Numerical study of stress-strain state of reinforced concrete slab in punching zone. IOP Conference Series: Materials Science and Engineering 775:7-11. https://doi.org/10.1088/1757899X/775/1/012136

8. Bompa D V., Elghazouli AY (2020) Nonlinear numerical simulation of punching shear behavior of reinforced concrete flat slabs with shear-heads. Frontiers of Structural and Civil Engineering 14:331-356. https://doi.org/10.1007/s11709-019-0596-5 
9. Genikomsou AS, Polak MA (2015) Finite element analysis of punching shear of concrete slabs using damaged plasticity model in ABAQUS. Engineering Structures 98:38-48. https://doi.org/10.1016/j.engstruct.2015.04.016

10. Abdul Rasoul ZMR, Taher HMAM (2019) Accuracy of concrete strength prediction behavior in simulating punching shear behavior of flat slab using finite element approach in abaqus. Periodicals of Engineering and Natural Sciences 7:1933-1949. https:// doi.org/10.21533/pen.v7i4.943

11. Boonpichetvong M, Pannachet T, Pinitkarnwatkul S (2016) Finite element modeling of concrete specimens confined with metal sheet strips. International Journal of Technology 7:1132-1140. https://doi. org/10.14716/ijtech.v7i7.4875

12. Moehle JP (1988) Strength of Slab-Column Edge Connections. ACI Structural Journal 85:89-98

13. Badan Standarisasi Nasional (2019) SNI 2847:2019 Persyaratan beton struktural untuk bangunan gedung dan penjelasan. Jakarta

14. Badan Standardisasi Nasional (2019) SNI-1726:2019 Tata Cara perencanaan ketahanan gempa untuk struktur bangunan gedung dan non gedung. Jakarta

15. Wiryadi IGG (2017) Analisis elemen hingga perilaku hubungan pelat-kolom beton bertulang akibat gaya geser dan momen tak imbang dua arah. Udayana University

16. Hognestad E (1951) A Study of Combined Bending and Axial Load in Reinforced Concrete Members. University of Illinois Bulletin Series 399:49. https:// doi.org/10.14359/7785

17. Lubliner J, Oliver J, Oller S, Oñate E (1989) A plastic-damage model for concrete. International Journal of Solids and Structures. https://doi. org/10.1016/0020-7683(89)90050-4

18. Lee J, Fenves GL (1998) Plastic-damage model for cyclic loading of concrete structures. Journal of Engineering Mechanics 124:892-900

19. Wosatko A, Genikomsou A, Pamin J, et al (2018) Examination of two regularized damage-plasticity models for concrete with regard to crack closing. Engineering Fracture Mechanics. https://doi. org/10.1016/j.engfracmech.2018.03.002
20. Tambusay A, Suprobo $P$, Faimun, Amiruddin AA (2016) Analyses Behavior of Slab-Column Connections Using ECC Material Based. EASEC 14.: https:// doi.org/10.13140/RG.2.1.1517.7367

21. Qingfu L, Wei G, Yihang K (2020) Parameter calculation and verification of concrete plastic damage model of ABAQUS. In: IOP Conference Series: Materials Science and Engineering. Institute of Physics Publishing

22. El-salakawy EF, Polak MA, Soliman MH (1998) Slab-column edge connections subjected to high moments. Can J Civ Eng 25:526-538

23. Sudarsana IK, Gegiranang Wiryadi IG, Adi Susila IG (2017) Analisis Perilaku Hubungan Pelat-Kolom Tepi Struktur Pelat Datar menggunakan Concrete Damage Plasticity (CDP) dalam Abaqus. Jurnal Spektran 5:

24. Viswanathan TS, Mohan GG, Santhi AS (2012) Shear stress distribution of flat-plate using Finite Element Analysis. International Journal of Civil and Structural Engineering 2.: https://doi.org/10.6088/ ijcser.00202030019

25. Comite Euro-International du Beton (2013) CEB-FIP Model Code for Concrete Structures 2010. Ernst \& Sohn, Berlin

26. Gardner NJ, Shao XY (1996) Punching Shear of Continuous Flat Reinforced Concrete Slabs. ACl Structural Journal 93:218 - 228

27. Sudarsana IK (2001) Punching Shear in Edge and Corner Column Slab Connections of Flat Plate Structures. University of Ottawa

28. Sherif AG, Dilger WH (1966) Critical Review of the CSA A23.3-94 Punching Shear Strength Provision for Interior Columns. Canadian Journal for Civil Engineering 23:998-1011 